\title{
NEOLIBERALISM'S WAR AGAINST HIGHER EDUCATION AND THE ROLE OF PUBLIC INTELLECTUALS
}

\author{
LA GUERRA DEL NEOLIBERALISMO CONTRA LA EDUCACIÓN SUPERIOR \\ $Y$ EL ROL DE LOS INTELECTUALES PÚBLICOS
}

\author{
Henry A. Giroux* \\ McMaster University, Ontario. \\ Recibido septiembre de 2015/Received September, 2015 \\ Aceptado noviembre de 2015/Accepted November, 2015
}

\begin{abstract}
RESUMEN
Bajo el reinado del neoliberalismo, las decisiones económicas y políticas no toman en cuenta los costos sociales y el pensamiento crítico y la responsabilidad social es todavía minada por la supresión de los disidentes, un asalto a la educación superior como una esfera democrática y pública, y un intento en progreso de suprimir el trabajo de los educadores cuya obra se esmera por conectar el conocimiento académico con importantes temas sociales y desarrolla formas de educación crítica cuyo objetivo es trasladar problemas privados en preocupaciones públicas mientras se promueve lo que Paulo Freire alguna vez en educación llamó la práctica de la libertad. Este artículo examina las cuestiones relacionadas con qué clase de educación se necesita para los estudiantes para ser ciudadanos informados y activos en un mundo que crecientemente ignora sus necesidades, o su futuro, y qué papel podrían tener los educadores en este proyecto como intelectuales públicos. El artículo argumenta que es tiempo para que los educadores desarrollen un lenguaje político en el cual los valores cívicos y la responsabilidad social -y las instituciones, tácticas, y propósitos a largo plazo para apoyarlos- lleguen a ser centrales para vigorizar y fortificar una nueva era de compromiso cívico, un sentido renovado de la acción social, y un apasionado movimiento social internacional con la visión, la organización y un conjunto de estrategias capaces de desafiar la pesadilla neoliberal que ahora asola el globo y vacía de significado la política y la democracia.

Palabras Clave: Neoliberalismo, Capitalismo de Casino, Pedagogía, Intelectuales Públicos, Democracia Radical, Educación Crítica, Permanencia en el Cargo, Valores basados en el Mercado.
\end{abstract}

\begin{abstract}
Under the rein of neoliberalism, economic and political decisions are removed from social costs and the flight of critical thought and social responsibility is further undermined by both the suppression of dissent, an assault on higher education as a democratic public sphere, and an ongoing attempt to suppress the work of educators whose work strives to connect scholarship to important social issues and develop forms critical education whose aim is to translate private troubles into public concerns while promoting what Paulo Freire once education as the practice of freedom. This article examines the related questions of what kind of education is needed for students to be informed and active citizens in a world that increasingly ignores their needs, if not their future, and what role might educators play in this project as public intellectuals. The article argues that it is time for educators to develop a political language in which civic values and social responsibility —and the institutions, tactics, and long-term commitments that support them-become central to invigorating and fortifying a new era of civic engagement, a renewed sense of social agency, and an impassioned international social movement with the vision, organization, and set of strategies capable of challenging the neoliberal nightmare that now haunts the globe and empties out the meaning of politics and democracy.
\end{abstract}

Key Words: Neoliberalism, Casino Capitalism, Pedagogy, Public Intellectuals, Radical Democracy, Critical Education, Tenure, Market-based Values.

* McMaster University Professor for Scholarship in the Public Interest, Department of English \& Cultural Studies. henry.giroux @ gmail.com 
Across the globe, a new historical conjuncture is emerging in which the attacks on higher education as a democratic institution and on dissident public voices in general-whether journalists, whistleblowers, or academics-are intensifying with sobering consequences (Giroux, 2007; Radack, 2012; Greenwald, 2014). The attempts to punish prominent academics such as Ward Churchill, Steven Salaita, and others are matched by an equally vicious assault on whistleblowers such as Chelsea Manning, Jeremy Hammond, and Edward Snowden and journalists such as James Risen. Under the aegis of what Risen calls the "homeland security-industrial complex" (Risen, 2014), it becomes difficult to separate the war on whistleblowers and journalists from the war on higher education-the institutions responsible for safeguarding and sustaining critical theory and engaged citizenship.

Marina Warner (2014) has rightly called these assaults on higher education, "the new brutalism in academia". It may be worse than she suggests. In fact, the right-wing defense of the neoliberal dismantling of the university as a site of critical inquiry in many countries is more brazen and arrogant than anything we have seen in the past and its presence is now felt in a diverse number of repressive regimes. For instance, the authoritarian nature of neoliberalism and its threat to higher education as a democratic public spheres was on full display recently when the multi-millionaire and Beijing-appointed leader of Hong Kong, Leung Chunying, told pro-democracy protesters that "allowing his successors to be chosen in open elections based on who won the greatest number of votes was unacceptable in part because it risked giving poorer residents a dominant voice in politics". Offering an unyielding defense for China's authoritarian political system, he argued that any candidate that might succeed him "must be screened by a 'broadly representative' nominating committee, which would insulate Hong Kong's next chief executive from popular pressure to create social provisions and allow the government to implement more business-friendly policies to address economic" issues (Bradsher \& Buckley, 2014). This is not just an attack on political liberty but also an attack on dissent, critical education, and public institutions that might exercise a democratizing influence on the nation. In this case, the autonomy of institutions such as higher education is threatened not only by the repressive practices of the state but also by neoliberal economic policies.
The hidden notion of politics that fuels this market-driven ideology also informs a more Western-style form of neoliberalism in which the autonomy of democratizing institutions are under assault not only by the state but also by the rich, bankers, hedge fund managers, and the corporate elite. In this case, corporate sovereignty has replaced traditional state modes of governance and now it is powerful corporate elites who despise the common good. As the South African Nobel Prize winner in literature, JM Coetzee (2013), points out, the new power elite "reconceive of themselves as managers of national economies" who want to turn universities into training schools equipping young people with the skills required by a modern economy". Viewed as a private investment rather than a public good, universities are now construed as spaces where students are valued as human capital, courses are determined by consumer demand, and governance is based on the Walmart model of labor relations. For Coetzee, this attack on higher education, which is not only ideological but also increasingly relies on the repressive, militaristic arm of the punishing state, is a response to the democratization of the university that that reached a highpoint in the 1960s all across the globe. In the last forty years, the assault on the university as a center of critique and democratization has intensified, just as the reach of this assault has expanded to include intellectuals, campus protesters, an expanding number of minority students, and the critical formative cultures that provide the foundation for a substantive democracy (Coetzee, 2013).

Coetzee's defense of education provides an important referent for those of us who believe that the university is nothing if it is not a public trust and social good; that is, a critical institution infused with the promise of cultivating intellectual insight, the civic imagination, inquisitiveness, risk-taking, social responsibility, and the struggle for justice. Rather than defining the mission of the university in terms that mimic market-based ideologies, modes of governance, and neoliberal policies, the questions that should be asked at this crucial time in American history concern how the mission of the university might be better understood with respect to both developing and safeguarding the interests of young people at a time of violence and war, the rise of a rampant anti-intellectualism, the emerging specter of authoritarianism, and the threat of nuclear and ecological devastation. What 
might it mean to define the university as a public good and democratic public sphere rather than as an institution that has aligned itself with market values and is more attentive to market fluctuations and investor interests than educating students to be critically engaged citizens? Or, as Zygmunt Bauman and Leonidas Donskis (2013) write: "how will we form the next generation of ... intellectuals and politicians if young people will never have an opportunity to experience what a non-vulgar, non-pragmatic, non-instrumentalized university is like?" It is in the spirit of such considerations that I first want to address those larger economic, social, and cultural interests that threaten this notion of education, especially higher education.

With the advance of a savage form of casino capitalism and its dreamworlds of consumption, privatization, and deregulation, not only are democratic values and social protections at risk, but also the civic and formative cultures that make such values and protections intelligible and consequential to a sustainable democratic society. As public spheres, once enlivened by broad engagements with common concerns, are being transformed into "spectacular spaces of consumption" and financial looting, the flight from mutual obligations and social responsibilities intensifies and has resulted in not only a devaluing of public life and the common good, but also a crisis in the radical imagination, especially in terms of the meaning and value of politics itself (Kurlantzick, 2013). One index of such a crisis, as Mike Davis points out, is that we live in an era in which there is a super saturation of corruption, cruelty, and violence" that fails any longer to outrage or even interest (Fisher, 2009)".

Thomas Frank (2012) goes a bit further insisting that "Over the course of the past few decades, the power of concentrated money has subverted professions, destroyed small investors, wrecked the regulatory state, corrupted legislators en masse and repeatedly put the economy through the wringer. Now it has come for our democracy itself". And, yet, the only questions being asked about knowledge production, the purpose of education, the nature of politics, and our understanding of the future are determined largely by market forces. In this discourse, education is reduced to training, public values are transformed into crude instrumental values, and, public and higher education are reduced to operating systems, posing problems that can only be solved through quantification, effective programming , numerical data and, most of all, austerity measures. This is a form of neoliberal or corporatized education wedded to market-driven values and the culture of positivism, one that lacks any democratic vision. This is the vision of accountants who have no interest in the public good.

The mantras of neoliberalism are now well known: government is the problem; society is a fiction; governance should be market-driven; deregulation and commodification are vehicles for freedom, social needs must be subordinated to self-interests, finance culture should govern all of social life, and higher education should serve corporate interests rather than the public good. In addition, the yardstick of profit has become the only viable measure of the good life while civic engagement and public spheres devoted to the common good are viewed by many politicians and their publics as either a hindrance to the goals of a market-driven society or alibis for government inefficiency and waste.

In a market-driven system in which economic and political decisions are removed from social costs, the flight of critical thought and social responsibility is further accentuated by what Zygmunt Bauman calls "ethical tranquillization (McCarthy, 2007)". One result is a form of depoliticization that works its way through the social order, removing social relations from the configurations of power that shape them, substituting what Wendy Brown (2006) calls "emotional and personal vocabularies for political ones in formulating solutions to political problems". Consequently, it becomes difficult for young people too often bereft of a critical education to translate private troubles into public concerns. As private interests trump the public good, public spaces are corroded and short-term personal advantage replaces any larger notion of civic engagement and social responsibility. Under the restricted rationality of the market, pubic spheres and educational realms necessary for students to imagine alternative futures and horizons of possibility begin to disappear.

The question of what kind of education is needed for students to be informed and active citizens in a world that increasingly ignores their needs, if not their future, is rarely asked (Aronowitz, 2008). In the absence of a democratic vision of schooling, it is not surprising that some colleges and universities are increasingly opening their classrooms to corporate interests, welcoming money from billionaire donors such as the conservative Koch brothers, 
standardizing the curriculum, instituting top-down governing structures, and generating courses that promote entrepreneurial values unfettered by social concerns or ethical consequences.

Central to this neoliberal view of higher education in the United States is a market-driven paradigm that seeks to eliminate tenure, dismantle unions, turn the humanities into a job preparation service, and transform most faculty into an army of temporary subaltern labor For instance, in the United States out of 1.5 million faculty members, 1 million are "adjuncts who are earning, on average, $\$ 20 \mathrm{~K}$ a year gross, with no benefits or healthcare, and no unemployment insurance when they are out of work (The Blog of Junct Rebellion, 2012)". Many adjuncts are earning less than entry level fast food workers and many "are on food stamps and (...) go to food donation centers (Saccaro, 2014)". The indentured service status of such faculty is put on full display as some colleges have resorted to using "temporary service agencies to do their formal hiring" (Jaschik, 2010).

There is little talk in this view of higher education about the history and value of shared governance between faculty and administrators, nor of educating students as critical citizens rather than potential employees of Walmart. There are few attempts to affirm faculty as scholars and public intellectuals who have both a measure of autonomy and power. Instead, faculty members are increasingly defined less as intellectuals than as technicians and grant writers or they are punished for raising their voices against various injustices. Students fare no better in this debased form of education and are treated as either clients, consumers, or as restless children in need of high-energy entertainment as was made clear in the 2012 Penn State scandal and the ever increasing football scandals at major universities, where testosterone fuelled entertainment is given a higher priority than substantive teaching and learning-to say nothing of student safety and protection. Precious resources are now wasted by colleges intent on building football stadiums, student dorms that mimic resort hotels, and other amenities that signal the Disneyification of higher education for students and the Walmart model of labor relations for faculty. For instance, High Point University seeks to attract students with its first-run movie theater, ice cream trucks, a steakhouse, outdoor hot tubs, and dorms with plasma-screen TVs" (Matlack, 2012). Such modes of education do not foster a sense of organized responsibility fundamental to a democracy. Instead, they encourage what might be called a sense of organized irresponsibility-a practice that underlies the economic Darwinism and civic corruption at the heart of a debased politics of consumption, finance, and privatization. When one combines the university as a Disneyfied entertainment center with labor practices that degrade and exploit faculty the result is what Terry Eagleton recently calls the "death of universities as centers of critique" (Eagleton, 2010).

\section{Higher Education and the Crisis of Legitimacy}

In the United States and increasingly in Canada, many of the problems in higher education can be linked to diminished funding, the domination of universities by market mechanisms, the rise of forprofit colleges, the intrusion of the national security state, and the weakened role of faculty in governing the university, all of which both contradicts the culture and democratic value of higher education and makes a mockery of the very meaning and mission of the university as a democratic public sphere. Decreased financial support for higher education stands in sharp contrast to increased support for tax benefits for the rich, big banks, the military, and mega corporations. Rather than enlarge the moral imagination and critical capacities of students, too many universities are now encouraged to produce would-be hedge fund managers, depoliticized students, and modes of education that promote a "technically trained docility" (Nussbaum, 2010). This reductionist notion of education works well with a funding crisis that is now used by conservatives as an ideological weapon to defund certain disciplines such as history, English, sociology, anthropology, minority studies, gender studies, and language programs as well as attack tenure, unions, and raise student tuition. One egregious example of this neoliberal approach to higher education is on full display in Florida where Governor Rick Scott's task force on education attempted to implement a policy that would lower tuition for degrees friendly to corporate interests in order to "steer students toward majors that are in demand in the job market" (Alvarez, 2012). Scott's utterly instrumental and anti-intellectual message is clear: the university wants people who can be trained for the workforce, not individuals who have the capacity 
to think critically and act in order to deepen and strengthen the fabric of a democratic society. Such practices suggest that the attack on higher education is not merely the consequence of an economic downturn but also the result of "a conservative-led campaign to end higher education's democratizing influence on the nation" (Nichol, 2008).

What has become clear is that universities are losing their sense of public mission, just as leadership in higher education is being stripped of any viable democratic vision. In the United States, college presidents are now called CEOs and move without apology between interlocking corporate and academic boards. With few exceptions, they are praised as fund raisers but rarely acknowledged for the quality of their ideas. Trustees have not only assumed more power in higher education, but are largely drawn from the ranks of business, and yet as in the Steven Salaita case are making judgments about faculty that they are unqualified to make. It gets worse.

In this new Gilded Age of money and profit, academic subjects gain stature almost exclusively through their exchange value on the market. For example, BB\&T Corporation, a financial holdings company, gave a \$1 million gift to Marshall University's business school on the condition that Atlas Shrugged by Ayn Rand (Congressman Paul Ryan's favorite book) be taught in a course. What happens to education when it is treated like a corporation? What are we to make of the integrity of a university when it accepts a monetary gift from powerful corporate interests or rich patrons demanding as part of the agreement the power to specify what is to be taught in a course or how a curriculum should be shaped? Some corporations and universities now believe that what is taught in a course is not an academic decision but a market consideration. In addition, many disciplines are now valued almost exclusively with how closely they align with what might be euphemistically called a business culture.

Not only does neoliberalism undermine both civic education and public values and confuse education with training, it also wages a war on what might be called the radical imagination. For instance, thousands of students in both the U.S. and Canada are now saddled with skyrocketing debts that will profoundly impact their lives and their future, likely forcing them away from public service jobs because the pay is too low to pay off their educational loans. Students find themselves in a world in which heightened expectations have been replaced by dashed hopes and a world of onerous debt (Fraser, 2013). Struggling to merely survive, the debt crisis represents a massive assault on the imagination by leaving little or no room to think otherwise in order to act otherwise. Not only does student debt kill the radical imagination in students by redirecting their talents to find ways to mostly survive, it also functions as Noam Chomsky points out as a as a device of indoctrination, entwined in a culture of fear and conformity. Precarity makes one vulnerable to fear, shuts down dissent, and breeds a form of participatory oppression. This is a particularly important insight in a society where the free circulation of ideas is not only being replaced by mass mediated ideas but where critical ideas are increasingly dismissed as either being too liberal, radical, or even seditious. As a result, we now live in a world in which the politics of disimagination dominates. For instance, public discourses that bear witness to a critical and alternative sense of the world are often dismissed because they do not advance narrow economic interests and increase the bottom line.

In a dystopian society, utopian thought becomes sterile and paraphrasing Theodor Adorno, thinking becomes an act of utter stupidity. Anti-public intellectuals now define the larger cultural landscape, all too willing to flaunt co-option and reap the rewards of venting insults at their assigned opponents while being reduced to the status of paid servants of powerful economic interests. But the problem is not simply with the rise of a right-wing cultural apparatus dedicated to preserving the power and wealth of the rich and corporate elite. As Stuart Hall remarked, the state of progressive thought is also in jeopardy in that, as he puts it, "The left is in trouble. It's not got any ideas, it's not got any independent analysis of its own, and therefore it's got no vision. It just takes the temperature...It has no sense of politics being educative, of politics changing the way people see things" (Williams, 2012). Of course, Hall is not suggesting the left has no ideas to speak of. He is suggesting that such ideas are often removed from the larger issue of what it means to address education and the production and reception of meaningful ways of thinking as a pedagogical practice that is central to politics itself. He is also saying that the left and progressives are often short of ideas that can move people. In other words, there is no sense 
of how to make ideas meaningful in order to make them critical and transformative.

The issue of politics being educative, of recognizing that matters of pedagogy, subjectivity, and consciousness are at the heart of political and moral concerns should not be lost on academics and students. As the late Pierre Bourdieu argued, it is important for all of us to recognize that the most important forms of domination are not only economic but also intellectual and pedagogical, and lie on the side of belief and persuasion. This suggests that it is crucial to recognize that academics and other cultural workers bear an enormous responsibility for challenging this form of domination. Nor should the relevance of education being at the heart of politics be lost on those of us concerned about inviting the public back into higher education and rethinking the purpose and meaning of higher education itself. Higher education must be defended as a public good, one that is indispensable to creating the formative culture necessary for students to learn how to govern rather than be governed. Only through such a formative and critical educational culture can students learn how to become individual and social agents, rather than disengaged spectators or uncritical consumers. At the very least, they should learn how to think otherwise and to act upon civic commitments that "necessitate a reordering of basic power arrangements" fundamental to promoting the common good and producing a strong democracy.

\section{Dreaming the Impossible}

Reclaiming higher education as a democratic public sphere begins with the crucial recognition that education is not solely about job training and the production of ethically challenged entrepreneurial subjects, but also about matters of civic engagement, critical thinking, civic literacy, and the capacity for democratic agency, action, and change. It is also inextricably connected to the related issues of power, inclusion, and social responsibility (Searl, 2012). If young people are to develop a deep respect for others, a keen sense of social responsibility, as well as an informed notion of civic engagement, education must be viewed as the cultural, political, and moral force that provides the knowledge, values, and social relations to make such democratic practices possible and connect human agency to an engaged notion of the civic imagination, social justice, and the politics of possibility.
Increasingly, public and higher education are characterized by pedagogies that disdain social responsibility, if not critical thinking itself. In an age that embraces trigger warnings, it is becoming official policy to both infantilize students and convince faculty that they should stay away from the disturbing and urgent problems that confront the larger society. Hiding behind appeals to balance and objectivity, it becomes difficult for educators to recognize that being committed to something does not cancel out what C. Wright Mills (2000) once called hard thinking. Teaching needs to be rigorous, self-reflective, and committed not to the dead zone of instrumental rationality but to the practice of freedom, to a critical sensibility capable of advancing the parameters of knowledge, addressing crucial social issues, and connecting private troubles and public issues.

Some academics claim that faculty should not address important social issues in either their research or teaching. To do so is to run the risk of not only becoming incapable of defending higher education as a vital public sphere, but also of having no influence over the conditions of their own intellectual labor. Without their intervention as public intellectuals, the university defaults on its role as a democratic public sphere willing to produce an informed public, enact and sustain a culture of questioning, and enable a critical formative culture that advances not only the power of the imagination but also what Kristen Case calls moments of classroom grace. Pedagogies of classroom grace allows students reflect critically on commonsense understandings of the world, and begin to question, however troubling, their sense of agency, relationship to others, and their relationship to the larger world. This is a pedagogy that asks why we have wars, massive inequality, a surveillance state, the commodification of everything, and the collapse of the public into the private. This is not merely a methodical consideration but also a moral and political practice because it presupposes the creation of critically engaged students can imagine a future in which justice, equality, freedom, and democracy matter.

Before his untimely death, Edward Said, himself an exemplary public intellectual, urged his colleagues in the academy to confront directly those social hardships that disfigure contemporary society and pose a serious threat to the promise of democracy. ${ }^{1}$ He urged them to assume the role of 
public intellectuals, wakeful and mindful of their responsibilities to bear testimony to human suffering and the pedagogical possibilities at work in educating students to be autonomous, self-reflective, and socially responsible. Said rejected the notion of a market-driven pedagogy that lacking a democratic project was steeped in the discourse of instrumental rationality and fixated on measurement. He insisted that when pedagogy is taken up as a mechanistic undertaking, it loses any understanding of what it means for students to "be thoughtful, layered, complex, critical thinker[s]" (Cunningham, 2013). For Said, such methodological reification was antithetical to a pedagogy rooted in the practice of freedom and attentive to the need to construct critical agents, democratic values, and modes of critical inquiry. On the contrary, he viewed it as a mode of training more suitable to creating cheerful robots and legitimating organized recklessness and legalized illegalities.

The famed economist, William Black goes so far as to argue that such stripped down pedagogies are responsible for creating what he calls criminogenic cultures, especially in business schools and economics departments at a number of Ivy League universities. This theme has been more recently taken up in the book, Excellent Sheep, by William Deresiewicz, which offers a stinging critique of the shark-like and survival-of the-fittest pedagogical environments at work in the elite universities. An indication of this crowning pedagogical disgrace can be found in Oscar winning documentary, Inside $J o b$, which showed how Wall Street bought off high profile economists from Harvard, Yale, MIT, and Columbia University. For instance, Glenn Hubbard, Dean of Columbia Business School and Martin Feldstein of Harvard got huge payoffs from a number of financial firms and wrote academic papers or opinion pieces favoring deregulation, while refusing to declare that they were on the payroll of Met Life, Goldman Sachs, or Merrill Lynch (Ferguson, 2012).

In opposition to such a debased view of educational engagement, Said argued for what he called a pedagogy of wakefulness. In defining and expanding on Said's pedagogy of wakefulness, and how it shaped his important consideration of academics as public intellectuals, I begin with a passage that I think offers tremendous insight on the ethical and political force of much of his writing. This selection is taken from his memoir, Out of Place, which describes the last few months of his mother's life in a New York hospital and the difficult time she had falling asleep because of the cancer that was ravaging her body. Recalling this traumatic and pivotal life experience, Said's meditation moves between the existential and the insurgent, between private pain and worldly commitment, between the seductions of a "solid self" and the reality of a contradictory, questioning, restless, and at times, uneasy sense of identity. He writes:

'Help me to sleep, Edward,' she once said to me with a piteous trembling in her voice that I can still hear as I write. But then the disease spread into her brain-and for the last six weeks she slept all the time-my own inability to sleep may be her last legacy to me, a counter to her struggle for sleep. For me sleep is something to be gotten over as quickly as possible. I can only go to bed very late, but I am literally up at dawn. Like her I don't possess the secret of long sleep, though unlike her I have reached the point where I do not want it. For me, sleep is death, as is any diminishment in awareness. ..Sleeplessness for me is a cherished state to be desired at almost any cost; there is nothing for me as invigorating as immediately shedding the shadowy half-consciousness of a night's loss than the early morning, reacquainting myself with or resuming what I might have lost completely a few hours earlier. I occasionally experience myself as a cluster of flowing currents. I prefer this to the idea of a solid self, the identity to which so many attach so much significance. These currents like the themes of one's life, flow along during the waking hours, and at their best, they require no reconciling, no harmonizing. They are 'off' and may be out of place, but at least they are always in motion, in time, in place, in the form of all kinds of strange combinations moving about, not necessarily forward, sometimes against each other, contrapuntally yet without one central theme. A form of freedom, I like to think, even if I am far from being totally convinced that it is. That skepticism too is one of the themes I particularly want to hold on to. With so many dissonances in my life I have learned actually to prefer being not quite right and out of place (Said, 2000).

Said posits here an antidote to the seductions of conformity and the lure of corporate money that insures, as Irving Howe (1990) once pointed out caustically, "an honored place for the intellectuals". 
For Said, it is a sense of being awake, displaced, caught in a combination of contradictory circumstances that suggests a pedagogy that is cosmopolitan and imaginative-a public affirming pedagogy that demands a critical and engaged interaction with the world we live in mediated by a responsibility for challenging structures of domination and for alleviating human suffering. This is a pedagogy that addresses the needs of multiple publics. As an ethical and political practice, a public pedagogy of wakefulness rejects modes of education removed from political or social concerns, divorced from history and matters of injury and injustice. Said's notion of a pedagogy of wakefulness includes "lifting complex ideas into the public space," recognizing human injury inside and outside of the academy, and using theory as a form of criticism to change things. ${ }^{2}$ This is a pedagogy in which academics are neither afraid of controversy nor the willingness to make connections between private issues and broader elements of society's problems that are otherwise hidden.

Being awake meant refusing the now popular sport of academic bashing or embracing a crude call for action at the expense of rigorous intellectual and theoretical work. On the contrary, it meant combining rigor and clarity, on the one hand, and civic courage and political commitment, on the other. A pedagogy of wakefulness meant using theoretical archives as resources, recognizing the worldly space of criticism as the democratic underpinning of publicness, defining critical literacy not merely as a competency, but as an act of interpretation linked to the possibility of intervention in the world. It pointed to a kind of border literacy in the plural in which people learned to read and write from multiple positions of agency; it also was indebted to the recognition forcibly stated by Hannah Arendt (1977) that "Without a politically guaranteed public realm, freedom lacks the worldly space to make its appearance".

I believe that Said was right in insisting that intellectuals have a responsibility to unsettle power, trouble consensus, and challenge common sense. The very notion of being an engaged public intellectual is neither foreign to nor a violation of what it means to be an academic scholar, but central to its very definition. According to Said (2001), academics have a duty to enter into the public sphere unafraid to take positions and generate controversy, functioning as moral witnesses, raising political awareness, making connections to those elements of power and politics often hidden from public view, and reminding "the audience of the moral questions that may be hidden in the clamor and din of the public debate".

The view of higher education as a democratic public sphere committed to producing young people capable and willing to expand and deepen their sense of themselves, to think the "world" critically, "to imagine something other than their own well-being," to serve the public good, take risks, and struggle for a substantive democracy has been in a state of acute crisis for the last thirty years (Newfield, 2008). When faculty assume, in this context, their civic responsibility to educate students to think critically, act with conviction, and connect what they learn in classrooms to important social issues in the larger society, they are often hounded by those who demand "measurable student outcomes," as if deep learning breaks down into such discrete and quantifiable units. What do the liberal arts and humanities amount to if they do not function as centers of critique, repositories for cultivating the radical imagination, and teach the practice of freedom? Gayatri Spivak (2010) provides a context for this question with her comment: "Can one insist on the importance of training in [in higher education] in [a] time of legitimized violence?"

C.Wright Mills (2000) was right in contending that higher education should be considered a "public intelligence apparatus, concerned with public issues and private troubles and with the structural trends of our time underlying them". He insists that academics in their roles as public intellectuals ought to transform personal troubles and concerns into social issues and problems open to critique, debate, and reason. Matters of translation, connecting private troubles with larger systemic considerations are crucial in helping "the individual become a self-educating [person], who only then would be reasonable and free". ${ }^{3}$ Yet, Mills also believed, rightly, that that criticism is not the only responsibility of public intellectuals. As Archon Fung (2011) points out, they can "also join with other citizens and young people to address social problems, aid popular movements and organizations in their efforts to advance justice, and sometimes work with governments "to construct a world that is more just and democratic".

For those of us who believe that education is more than an extension of the business world, it is 
crucial to address a number of issues that connect the university to the larger society while stressing the educative nature of politics as part of a broader effort to create a formative culture that supports the connection between critique and action and redefines agency in the service of the practice of freedom and justice. Let me mention just a few. First, educators can address the relationship between the attack on the social state and the transformation of higher education into an adjunct corporate power. The attack on higher education is difficult to fully comprehend outside of the attack on the welfare state, social provisions, public servants, and democratic public spheres. Nor can it be understood outside of the production of the neoliberal subject, one who is atomized, unable to connect private issues to larger public considerations, and is taught to believe in a form of radical individualism that enables a fast withdrawal from the public sphere and the claims of economic and social justice. As Stefan Collini (2014) has argued, under the regime of neoliberalism, the "social self' has been transformed into the "disembedded individual," just as the notion of the university as a public good is now repudiated by the privatizing and atomistic values at the heart of a hyper-market driven society.

Clearly, in any democratic society, education should be viewed as a right, not an entitlement. This suggests a reordering of state and federal priorities to make that happen. Much needed revenue can be raised by putting into play even a limited number of reform policies in which, for instance, the rich and corporations would be forced to pay a fair share of their taxes, a tax would be placed on trade transactions, and tax loopholes for the wealthy would be eliminated. It is well known that the low tax rate given to corporations is a major scandal. For instance, the Bank of America paid no taxes in 2010 and "got $\$ 1.9$ billion tax refund from the IRS, even though it made $\$ 4.4$ billion in profits" (Snyder, 2013).

In addition, academics can join with students, public schools teachers, unions, and others to bring attention to wasteful military spending that if eliminated could provide the funds for a free public higher education for every qualified young person in the country. While there is growing public concern over rising tuition rates along with the crushing debt students are incurring, there is little public outrage from academics over the billions of dollars wasted on a massive and wasteful military budget and arms industry. One example of military waste is evident in a military project such as the F-35 Stealth Fighter jet, which over the lifetime of the project is expected to cost $\$ 1.5$ trillion dollars. Democracy needs a Marshall Plan in which funding is sufficient to make all levels of education free, while also providing enough social support to eliminate poverty, hunger, inadequate health care, and the destruction of the environment. There is nothing utopian about the demand to redirect money away from the military, powerful corporations, and the upper 1 percent.

Second, addressing these tasks demands a sustained critique of the transformation of a market economy into a market society along with a clear analysis of the damage it has caused both at home and abroad. Power, particularly the power of the largest corporations, has become more unaccountable and "the subtlety of illegitimate power makes it hard to identify" (George, 2014). The greatest threat posed by authoritarian politics is that it makes power invisible and hence defines itself in universal and commonsense terms, as if it is beyond critique and dissent. Moreover, disposability has become the new measure of a savage form of casino capitalism in which the only value that matters is exchange value. Compassion, social responsibility, and justice are relegated to the dustbin of an older modernity that now is viewed as either quaint or a grim reminder of a socialist past. This suggests, as Angela Davis, Michelle Alexander, and others have argued that there is a need for academics and young people to become part of a broader social movement aimed at dismantling the repressive institutions that make up the punishing state. The most egregious example of which is the prison-industrial complex, which drains billions of dollars in funds to put people in jail when such resources could be used to fund public and higher education. As Ferguson (2012) makes painfully clear, the police have become militarized, armed with weapons from the battlefields of Iraq and Afghanistan. The United State prison system locks up more people than any other country in the world, and the vast majority of them are people of color. Moreover, public schools are increasingly modeled after prisons and are implementing policies in which children are arrested for throwing peanuts at a school bus or violating a dress code. The punishing state is a dire threat to both public and higher education and democracy itself. The American public does not need more prisons; it needs more 
schools, accessible, low cost health services, and a living wage for all workers. This type of analysis suggests that progressives and others need a more comprehensive understanding of how politics and power are interrelated, of how different registers of oppression mutually inform each other and can be better understood in terms of their connections and deeply historical and social relations.

Third, academics, artists, journalists and other young people need to connect the rise of subaltern, part-time labor-or what we might call the Walmart model of model of wealth and labor relations-in both the university and the larger society to the massive inequality in wealth and income that now corrupts every aspect of American politics and society. No democracy can survive the kind of inequality in which "the 400 richest people... have as much wealth as 154 million Americans combined, that's 50 percent of the entire country [while] the top economic 1 percent of the U.S. population now has a record 40 percent of all wealth and more wealth than 90 percent of the population combined" (DeGraw, 2011). The Koch brothers made 3 million an hour on their dividends in 2012. Moreover, they "made enough money in one second to feed one homeless woman on food stamps for an entire year" (Buchheit, 2013). Of course, there is more at stake here than making visible the vast inequities in educational and economic opportunities and the corruption of the political process, there is also the corrosion of democracy itself. Democracy in the United States is on life support because, as a recent Princeton University study noted, it has been hijacked by a free-floating class of ultra-rich and corporate powerbrokers and transformed into an oligarchy "where power is effectively wielded by a small number of individuals (Mckay, 2014)".

Fourth, academics need to fight for the rights of students to get a free education, be given a formidable and critical education not dominated by corporate values, and to have a say in the shaping of their education and what it means to expand and deepen the practice of freedom and democracy. In many countries such as Germany, France, Denmark, Cuba, and Brazil, post-secondary education is free because these countries view education not as a private right but as a public good. Yet, in some of the most advanced countries in the world such as the United States and Canada, young people, especially from low income groups have been excluded from getting a higher education and, in part, this is because they are left out of the social contract and the discourse of democracy. They are the new disposables who lack jobs, a decent education, hope, and any semblance of a life better than that of their parents. They are a reminder of how finance capital has abandoned any viable vision of a better future for young people. Youth have become a liability in the world of high finance, a world that refuses to view them as important social investments. And the consequences are terrifying. As Jennifer M. Silva (2013) points out in her book, Coming Up Short, coming of age for young people "is not just being delayed but fundamentally dismantled by drastic economic restructuring, profound cultural transformations, and deepening social inequality". The futures of young people are being refigured or reimagined in ways that both punish and depoliticize them. Silva writes that many young people are turning away from politics, focusing instead on the purely personal and emotional vocabularies of self-help and emotional self-management.

Finally, there is a need to oppose the ongoing shift in power relations between faculty and the managerial class. Too many faculty are now removed from the governing structure of higher education and as a result have been abandoned to the misery of impoverished wages, an excessive number of classes to teach, no health care, and few, if any, social benefits. As Benjamin Ginsburg points out, administrators and their staffs now outnumber full time faculty accounting for two-thirds of the increase in higher education costs in the past 20 years. This is shameful and is not merely an education issue but a deeply political matter, one that must address how neoliberal ideology and policy has imposed on higher education an anti-democratic governing structure.

We may live in the shadow of the authoritarian corporate state, but the future is still open. The time has come to develop a political language in which civic values and social responsibility-and the institutions, tactics, and long-term commitments that support them-become central to invigorating and fortifying a new era of civic engagement, a renewed sense of social agency, and an impassioned international social movement with the vision, organization, and set of strategies capable of challenging the neoliberal nightmare that now 
haunts the globe and empties out the meaning of politics and democracy.

These may be dark times, as Hannah Arendt once warned, but they don't have to be, and that raises serious questions about what educators are going to do within the current historical climate to make sure that they do not succumb to the authoritarian forces circling the university, waiting for the resistance to stop and for the lights to go out. Resistance is no longer an option, it is a necessity.

\section{References}

Álvarez, L. (9 de Diciembre de 2012). Florida May Reduce Tuiton for Select Majors. New York Times. Recuperado de: http:// www.nytimes.com/2012/12/10/education/florida-may-reducetuition-for-select- majors.html?r=0

Arendt, H. (1977). Between Past and Future: Eight Exercises in Political Thought. New York: Penguin.

Aronowitz, S. (2004). Against Schooling: Education and Social Class. Social Text, 22 (2), 13-35.

Bauman, Z. \& Donskis, L. (2013). Moral Blindness: The loss of Sensitivity in Liquid Modernity. Cambridge: Polity Press.

Bradsher, K. \& Buckley, C. (20 de Octubre de 2014). Hong Kong Leader Reaffirms Tough Stance on Elections and Economic Discontent. New York Times. Recuperado de: http://www.nytimes. com/2014/10/21/world/asia/leung-chun-ying-hong-kong-chinaprotests.html?hp\&action=click\&pgtype $=$ Homepage \&version $=H$ pSumSmallMedia\& module=first-column-region\&region=topnews\&WT.nav=top-news

Brown, W. (2006). Regulating Aversion: Tolerance in the Age of Identity and Empire. NJ: Princeton University Press.

Buchheit, P. (27 de Noviembre de 2013). 4 ways the Koch brothers wealth is incomprehensible. Salon. Recuperado de: http://www.salon.com/2013/11/27/4_ways_the_koch_brothers_wealth_is_incompre hensible_partnerl

Coetzee, J. (1 de noviembre de 2013). JM Coetzee: Universities head for extinction. Mail \& Guardian. Recuperado de: http:// mg.co.za/article/2013-11-01-universities-head-for- extinction

Collini, S. (2014). Response to Book Review Symposium: Stefan Collini, What are Universities For?. Sociology, 49 (4), 399-406.

Cunningham, M. (1 de marzo de 2013). Re.imagining Dissent. Guernica Magazine. Recuperado de: http://www.guernicamag. com/interviews/re-imagining-dissent/

DeGraw, D. (11 de Agosto de 2011). Meet the Global Financial Elites Constrlling \$46 Trillion in Wealth. Alternet. Recuperado de: http://www.alternet.org/story/151999/meet_the_global_financial_elites_controlling _\$46_trillion_in_wealth

Eagleton, T. (17 de Diciembre de 2010). The Death of Universities. The Guardian. Recuperado de: http://www.theguardian.com/ commentisfree/2010/dec/17/death-universities- malaise-tuition-fees

Ferguson, C. (2012). Predator Nation: Corporate Criminals, Political Corruption, and the Hijacking of America. New York: Crown Press.

Frank, T. (Abril de 2012). It's a rich man's world: How billionaire backers pick America's candidates. Harper's Magazine. Recuperado de: http://harpers.org/archive/2012/04/0083856
Fraser, S. (29 de Enero de 2013). The Politics of Debt in America: From Debtor's Prison to Debtor Nation. TomDispatch. com. Recuperado de: http://www.tomdispatch.com/dialogs/ print $/$ id $=175643$

Fung, A. (9 de septiembre de 2011). The Constructive Responsability of intellectuals. Boston Review. Recuperado de: http://www.bostonreview.net/BR36.5/archon_fung_noam_chomsky_responsibility_of_intellectuals.php

George, S. (2014). State of Corporations: The rise of Illegitimate Power and the Threat to Democracy. State of Power. Recuperado de: http://www.tni.org/sites/www.tni.org/files/download/ state_of_power-6feb14.pdf

Giroux, H. (2007). The University in Chains: Confronting the Military-Industrial-Academic Complex. New York: Paradigm.

- . - (2014). Neoliberalism's War on Higher Education. Chicago: Haymarket.

Graeber, D. (2012). Debt: The First 5,000 Years. New York: Melville House.

Greenwald, G. (2014). No Place to Hide. New York: Signal.

Howe, I. (1990). This Age of Conformity. New York: Harcourt Brace Jovanovic.

Kurlanzick, J. (2013). Democracy in Retreat. New Haven: Yale University Press. En Fisher, M. Capitalist Realism (p. 11). Washington: Zero Books.

Jaschik, S. (9 de Agosto de 2010). Making Adjuncts TempsLiterally. Inside Higher Ed. Recuperado de: http://www. insidehighered.com/news/2010/08/09/adjuncts

Matlack, C. (9 de abril de 2012). Bubble U.: High Point University. Bloomberg Business Week. Recuperado de: http://www.businessweek.com/articles/2012-04-19/ bubble- u-dot-high-point-university\#p3

McCarthy, G. (Febrero de 2007). The Social Edge Interview: Zygmunt Bauman. The Social Edge. Recuperado de: http:// webzine.thesocialedge.com/interviews/the-social-edge- interviewsociologist-and-author-zygmunt-bauman/

McKay, T. (16 de Abril de 2014). Princeton Concludes What Kind of Government America Really Has, and It's Not a Democracy. Popular Resistance. Recuperado de: http://www.policymic.com/ articles/87719/princeton-concludes-what-kind-of- governmentamerica-really-has-and-it-s-not-a-democracy

Mills, C. W. (2000). On politics. En C. Mills. The Sociological Imagination. Oxford: Oxford University Press. 
Newfield, C. (2008). Unmaking the Public University: The Forty-Year Assault on the Middle Class. Cambridge: Harvard University Press.

Nichol, G. (31 de octubre de 2008). Public Universities at Risk Abandoning Their Mission. The Chronicle of Higher Education. Recuperado de: http://chronicle.com/weekly/v54/ i30/30a02302.htm

Nussbaum, M. (2010). Not For Profit: Why Democracy Needs The Humanities. New Jersey: Princeton University Press.

Radack, J. (9 de abril de 2012). Obama targets journalists. Salon. Recuperado de: http://www.salon.com/2012/04/09/ journalists_casualties_in_the_war_on_whistleblo wers/

Risen, J. (2014). Pay at Any Price. New York: Houghton Mifflin.

Saccaro, M. (21 de septiembre de 2014). Professors on food stamps: The Shocking true story of academia in 2014. Salon. Recuperado de: http://www.salon.com/2014/09/21/professors_on_ food_stamps_the_shocking_true_story_of_academia_in_2014/

Said, E. (2001). On Defiance and Taking Positions, "Reflections On Exile and Other Essays". Cambridge: Harvard University Press.

- _ - (2000). Out of Place: A Memoir. New York: Vintage.
Searls, S. (2012). On the Civic Function of Intellectuals Today. En Olson, G. \& Worsham, L. (Ed.), Education as Civic Engagement: Toward a More Democratic Society (pp. 9-17). Boulder: Paradigm Publishers.

Silva, J. (2013). Coming Up Short: Working-Class Adulthood in Age of Uncertainty. New York: Oxford University Press.

Snyder, M. (19 de Febrero de 2013). You won't believe who is getting away with paying zero taxes while the middle class gets hammered. Infowars.com. Recuperado de: http://www.infowars.com/ abolish-the-income-tax-you-wont-believe-who-is- getting-awaywith-paying-zero-taxes-while-the-middle-class-gets-hammered/

Spivak, G. (2010). Changing Reflexez: Interview with Gayatri Chakravorty Spivak. Works and Days, 28 (55).

The blog of Junct Rebellion. (12 de agosto de 2012). Re: How The American University was Killed, in Five Easy Steps [Artículo en un blog]. Recuperado de: http://junctrebellion.wordpress.com/2012/08/12/ how-the-american-university-was- killed-in-five-easy-steps/

Warner, M. (11 de septiembre de 2014). Diary Marina Warner. The London Review of Books. Recuperado de: http://www.lrb. co.uk/v36/n17/marina-warner/diary

Williams, Z. (11 de febrero de 2012). The Saturday Interview: Stuart Hall. The Guardian. Recuperado de: http://www.guardian. co.uk/theguardian/2012/feb/11/saturday- interview-stuart-hall

\section{Notes}

1 I have used this example in other pieces, and I use it again because of its relevance.

2 Said, Out of Place, p. 7.

$3 \quad$ Ibid. Mills, "On Politics", p. 186. 